$$
\begin{aligned}
& \text { بررسى اثر ضدميكروبى عصاره متانولى و آبى گَل ابريشم مصرى } \\
& \text { ويدا تفكرى و نسيم نصيرى }
\end{aligned}
$$

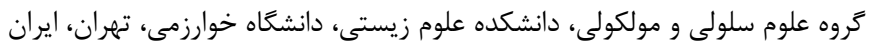

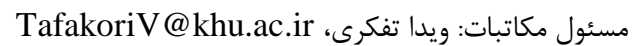

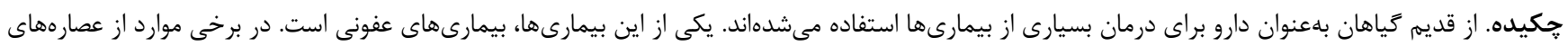

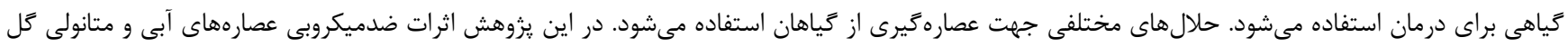

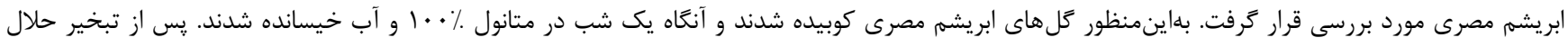

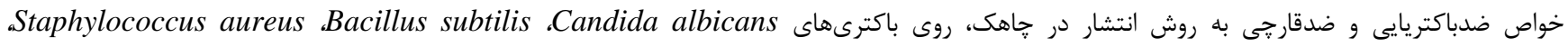

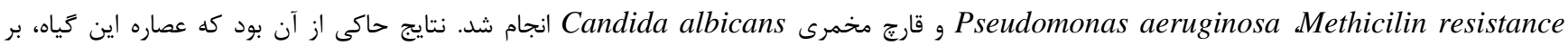

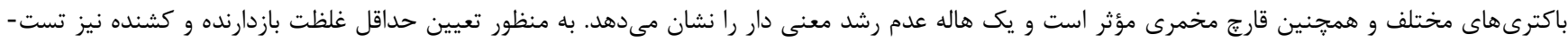

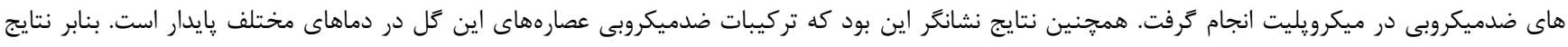

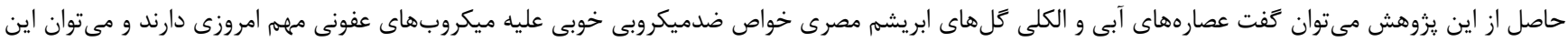

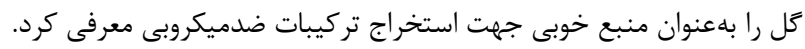

$$
\text { وازههاى كليدى. باكترى، بازدارنده، خاهك، كشنده، مخمر }
$$

\title{
Anti-microbial effects of aqueous and methanolic extracts of Erythrostemon gilliesii
}

\author{
Vida Tafakori \& Nasim Nasiri \\ Department of Cell and Molecular Sciences, Faculty of Biological Sciences, Kharazmi University, Tehran. Iran \\ Correspondent Author: Vida Tafakori, TafakoriV@khu.ac.ir
}

\begin{abstract}
Plants have been used as medicines in the treatment of diseases from the past to present. In this research, the antimicrobial effects of aqueous and methanolic extracts of Erythrostemon gilliesii were studied. For this purpose, fresh flowers were ground and then macerated in methanol $100 \%$ and water overnight. After the evaporation of solvents, anti-microbial activities of the concentrated extracts were evaluated by the well-diffusion method on Klebsiella pneumoniae, Pseudomonas aeroginosa, Methicilin resistance, Staphylococcus aureus, Bacillus subtilis and Candida albicans. The results showed that the extracts were effective on different bacteria and yeasts. In order to determine the minimum inhibitory concentration (MIC) and minimum biocidal concentration (MBC), anti-microbial tests were performed in micro-plates. Subsequently, the results indicated that the extracts were stable at different temperatures. The aqueous and methanolic extracts of the flowers of $E$. gilliesii had exhibited anti-microbial effects against important infectious microbes and could be introduced as an excellent source for anti-microbial agents.
\end{abstract}

Keywords. Bacteria, Biocidal, Inhibitory, well, yeast

Received 08.08.2018/ Revised 26.02.2019/ Accepted 04.03.2019/ Published 20.01.2020

دريافت: د 
مسطح و كشيده است. اين درختجه بومى آرزانتين است اما تقريبا

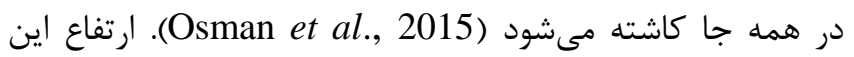

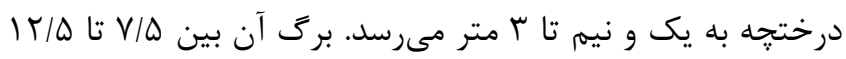

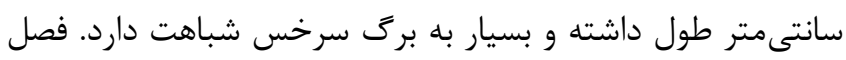

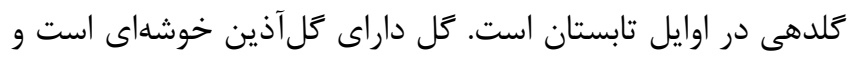

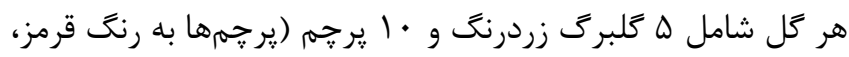
بلند با طولى بيشتر از • · سانتىمتر است (Link et al., 1840).

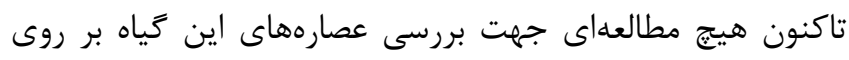

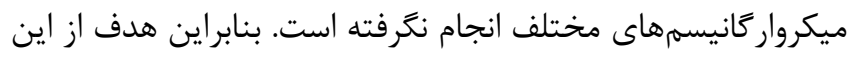

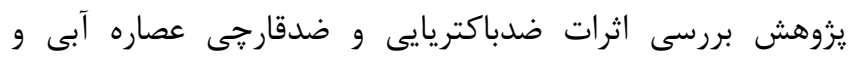

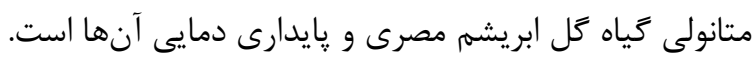

\section{مواد و روشها}

انتخاب كياه كل ابر يشم مصرى و استخراج عصاره آن

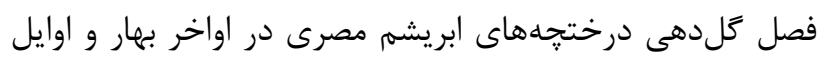

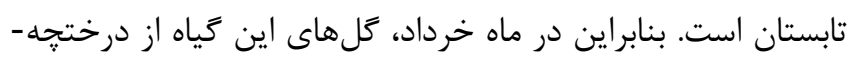

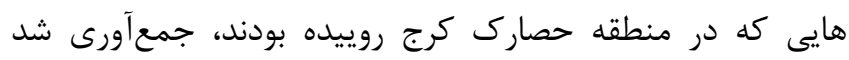

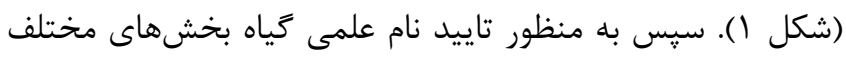

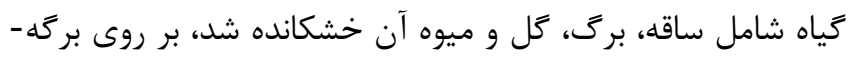

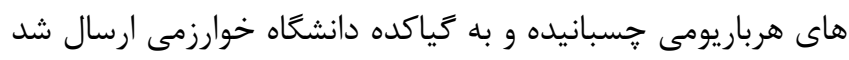

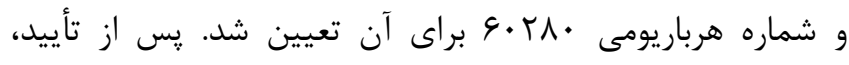
مراحل بعدى كار انجام كرفت.

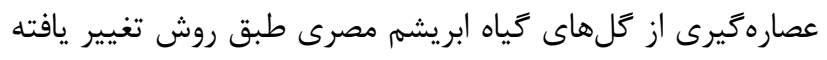
Stankovi'c

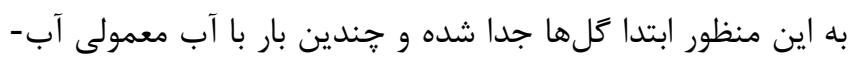

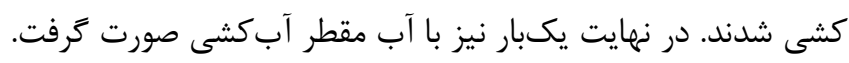

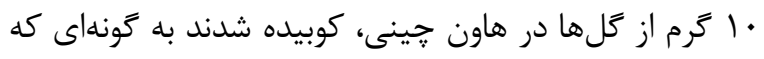

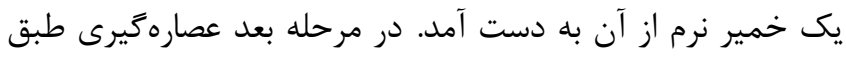

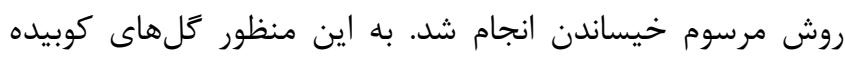

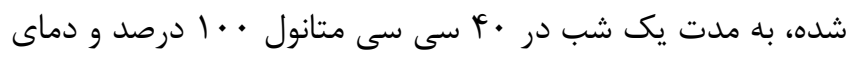

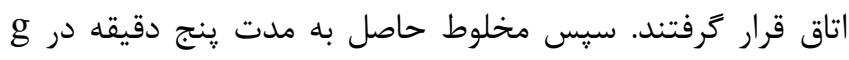

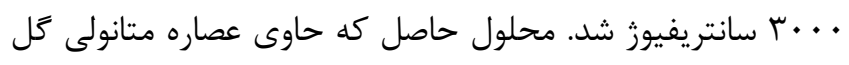
ابريشم مصرى است، زير هود شيميايى قرار ترفت تا حلال متانول مارل

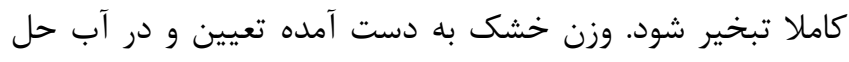

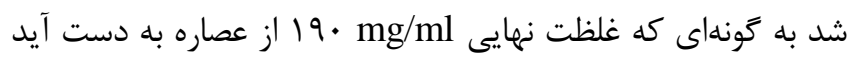

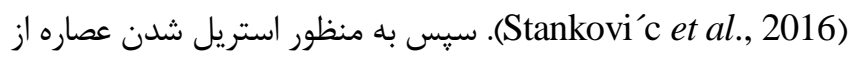
فيلترهاى سر سرنكى זr/ • ميكرون استفاده شد. همه مراحل ذكرشده
مقلمها

براى قرنهاى متمادى، گياهان به عنوان دارو و به منظور درمان

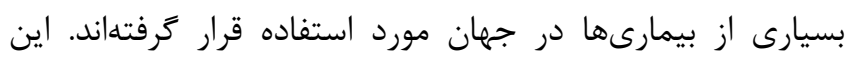

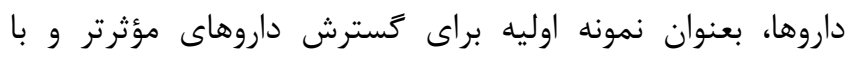
سميت كمتر، استفاده مى كردند (Sharma et al., 2009).

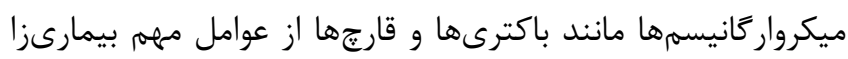

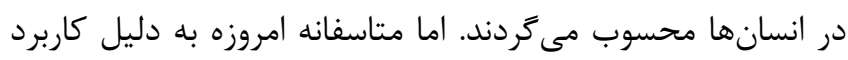

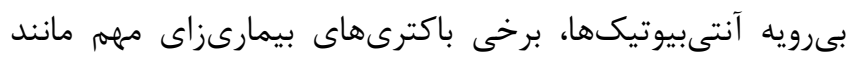

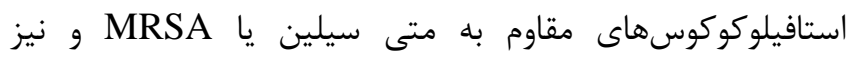

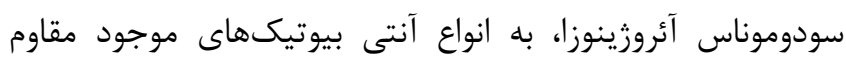
شدهاند و سبب بروز عفونتهاى غيرقابل درمان در انسان شدهاند

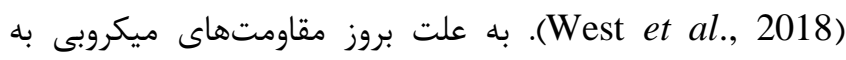

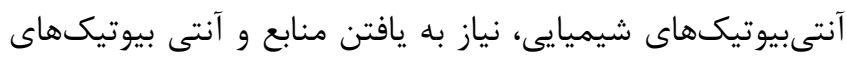

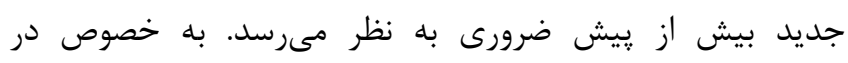

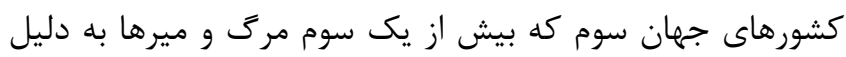

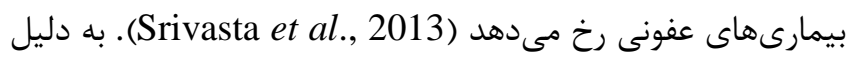

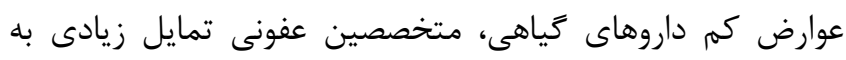

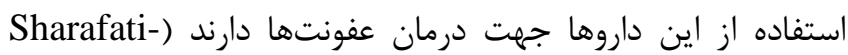
(chaleshtori et al., 2010 تركيبات آنها به عنوان جايكزينى براى آنتىبيوتيكهاى شيميايى

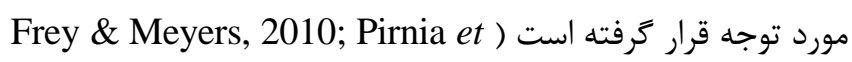

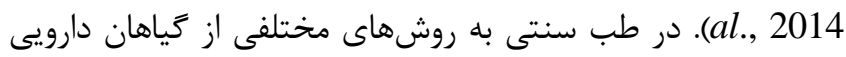

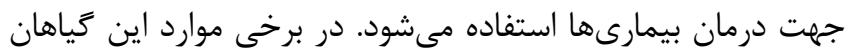

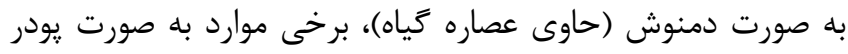

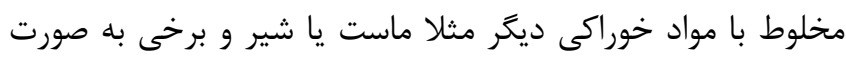

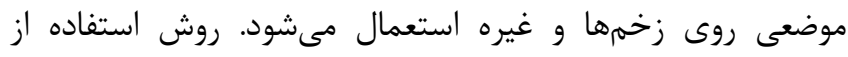

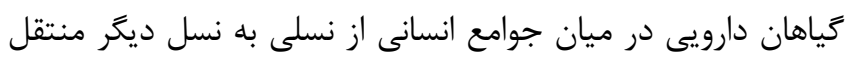

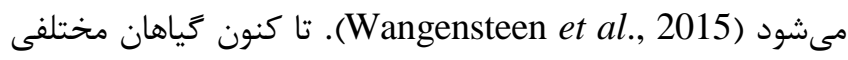
در طب سنتى استفاده شدهاند. برخى از اين گياهان از جمله كياهان

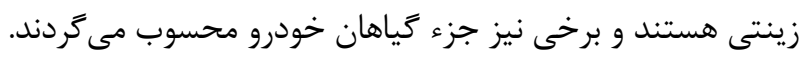

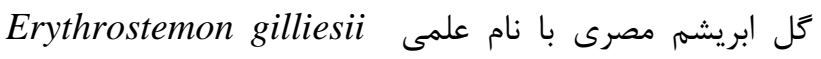
Caesalpinia gilliesii (Hook.) (مترادف) (Hook.) Klotzsch Poinciana ،Caesalpinia macrantha Delile D.Dietr (Prosopis gillesii (Hook.) Macloskie gilliesii Hook. شناخته مىشود. اين گياه جزو درختجههاى زينتى دوليهاى ها است

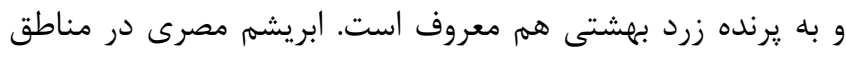

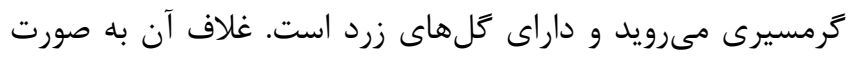




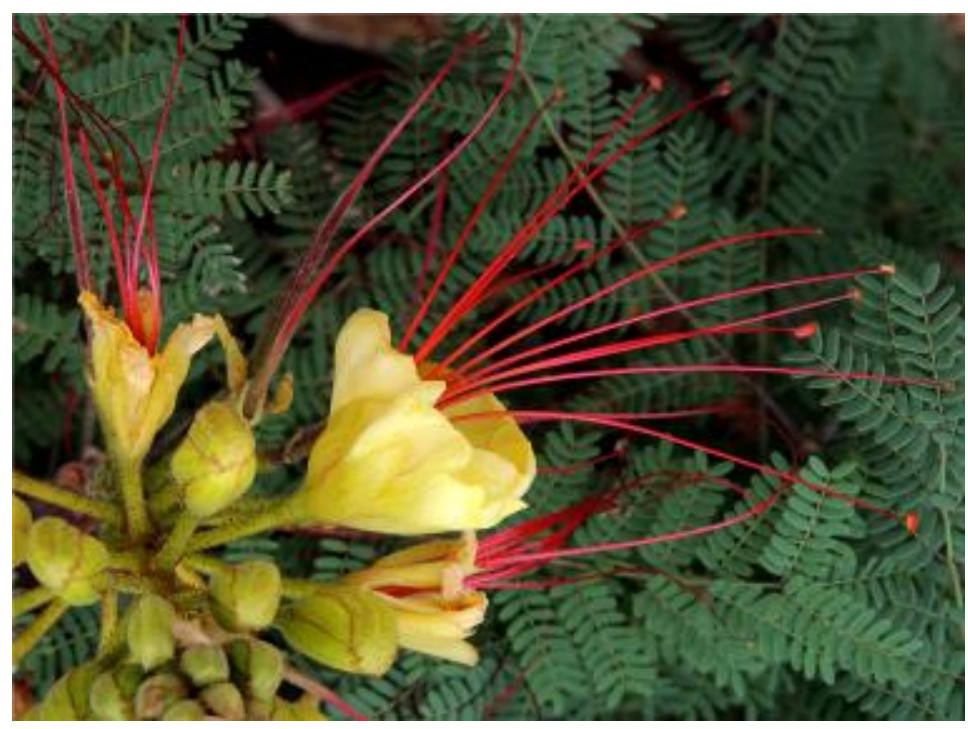

شكل ا- كل ابريشم مصرى.

Fig. 1. Erythrostemon gilliesii flower.

جذب سطح محيط كشت شدند، توسط إيليكاتور پِلاستيكى استريل

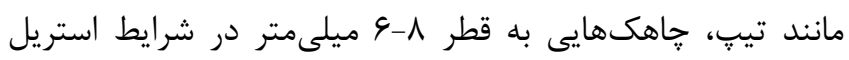

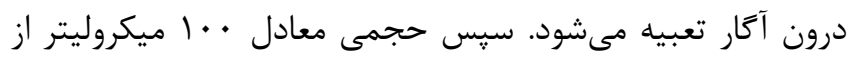

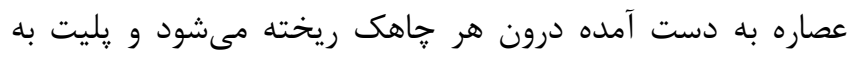

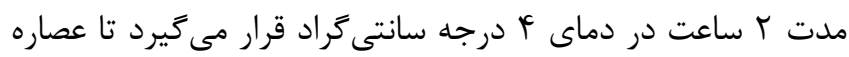

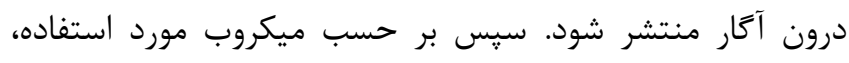

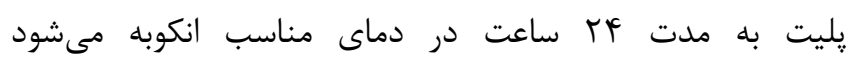

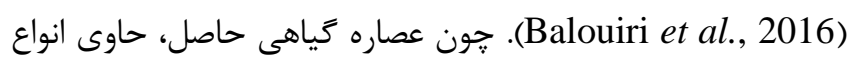

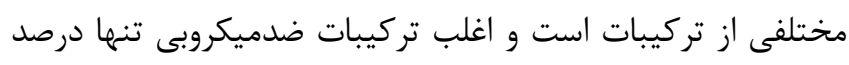

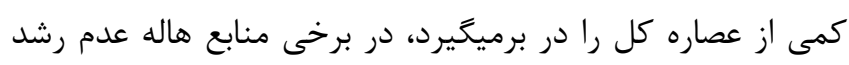

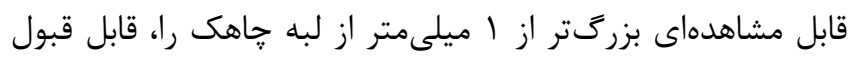

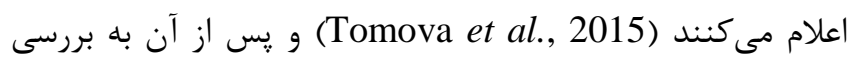

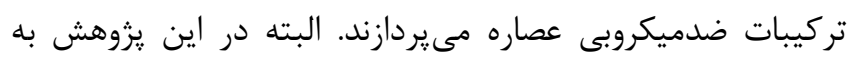

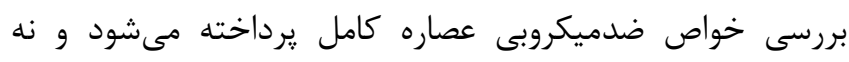

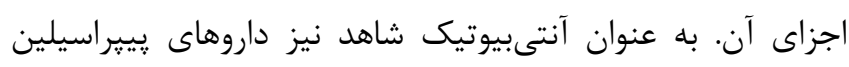

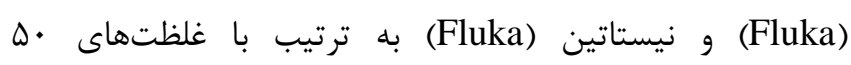

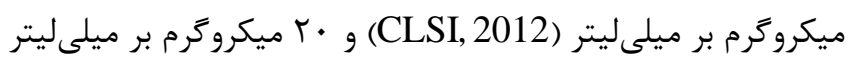

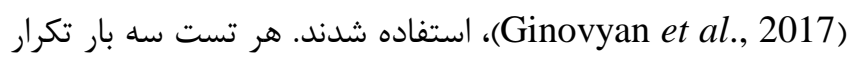

\section{شد.}

تعيين حداقل غلظت بازدارنده و كشنده ميكروبى

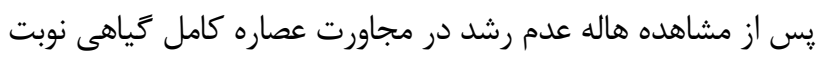

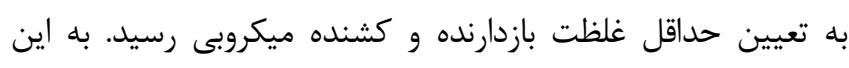

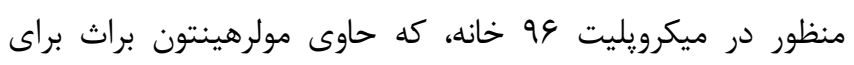

در بالا در مورد حلال آبى هم صورت گرفت. يعنى به جاى متانول از آب به عنوان حلال جهت عصارهخيرى استفاده شد. در مورد عصاره آبى غلظت نهايى بدست آمده mg/ml r mg به به دست آمد. ميكرواركانيسمهاى مورد استفاده و محيطهاى كشت باكترىهاى گرم منفى مورد استفاده در اين يروهش عبارت بودئن

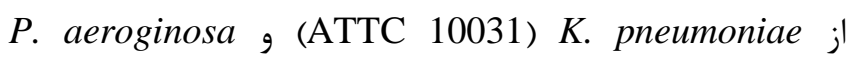
و باكترىهاى ₹رم مثبت مورد استفاده عبارت (ATTC 9027) بودند از ATTC ) 33593). به منظور بررسى خواص ضدقارجى عصارههاى به دست آمده نيز از قارج مخمرى ATTC 10231) C. albicans) استفاده شد. طبق استانداردهاى Clinical \& Laboratory CLSI Standards Institute) كشت مولرهينتون مايع و جامد و گونه قارجى نيز روى محيط كشت مولرهينتون مايع و جامد واجد r درصد كلوكز، كشت داده شدند (Balouiri et al., 2016). تمامى سويه (ذهاى ميكروبى از بانك ميكروبى مركز ملى ذخائر زنتيكى و زيستى ايران تهيه

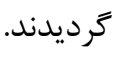
بررسى اوليه خواص ضدميكروبى عصارههاى تياهى

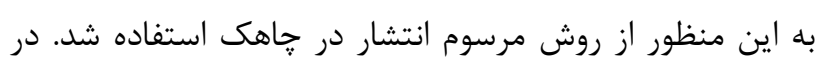

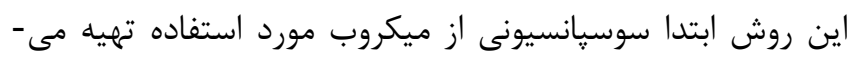

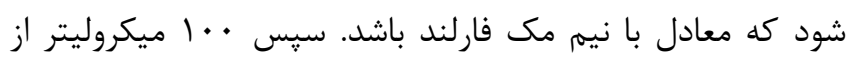
ميكروب مورد استفاده توسط سواب استريل روى سطح محيط كشت جامد كسترده مىشود. يس از • إ دقيقه كه ميكروب مورا كاملا 
Subtilis

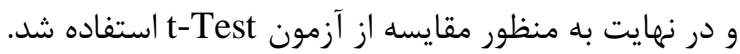

نتنايج

عصاره كيرى از گل ابريشم مصرى رنغ عصاره متانولى حاصل از گل هاى ابريشم مصرى، قرمز تيره و

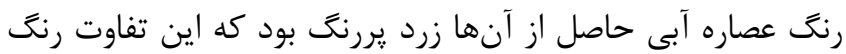

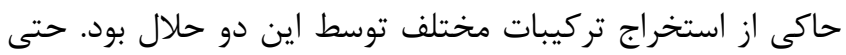

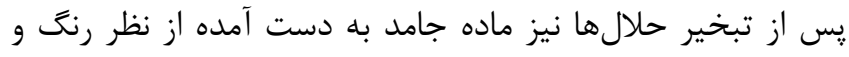

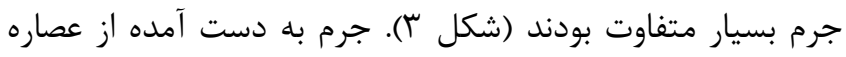
آبى بيشتر از عصاره متانولى بود.

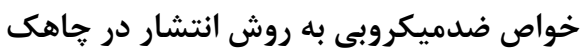

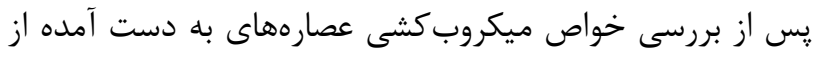
كل ابريشم مصرى، مشخص شد كه اين عصارهها بر روى اغلب

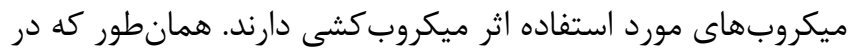

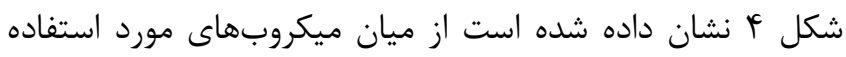

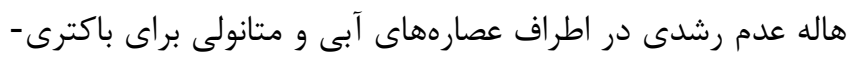

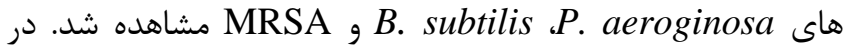
مورد قارج مخمرى C. albicans فقط در اطراف عصاره آبى هاله عدم رشد مشاهده شد.

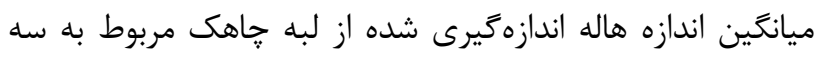

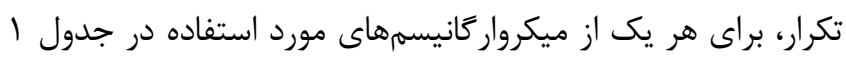

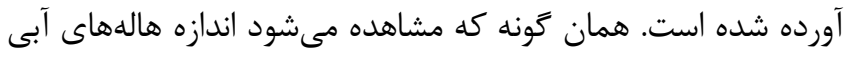

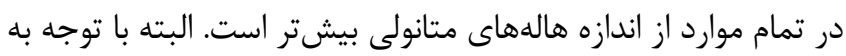

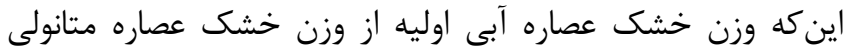

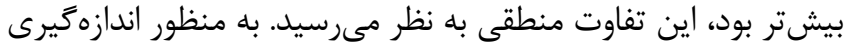

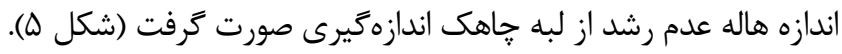
حداقل غلظت بازدارنده و كشنده ميكروبى ازئ لند

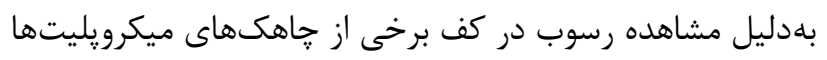

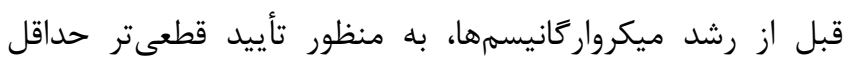
غلظت بازدارنده يس از يك شب انكوباسيون، از زاهكهايى كه

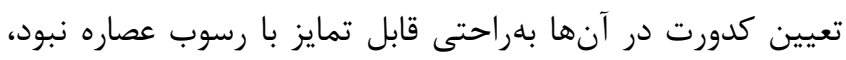

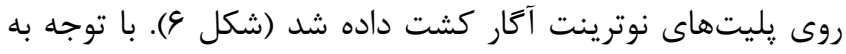

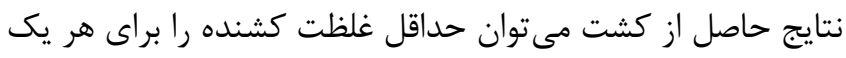

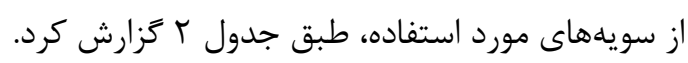

باكترىها و مولرهينتون براث به همراه كلوكز براى مخمر بود، سريال

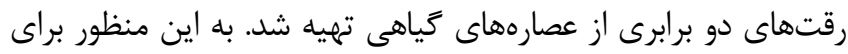

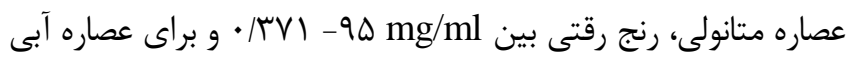

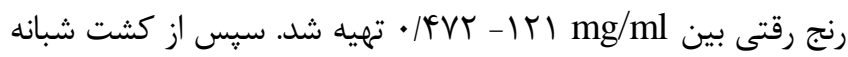

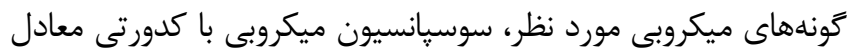

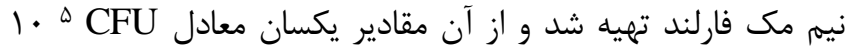

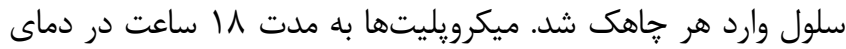

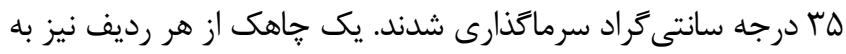
عنوان شاهد رشد بدون هيج عصاره ميكروبى در نظر كرفته شدراس

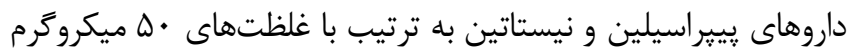

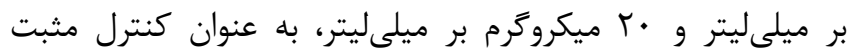

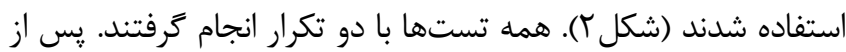

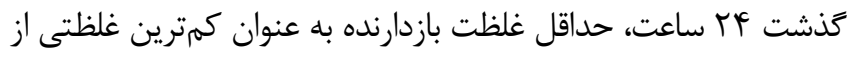

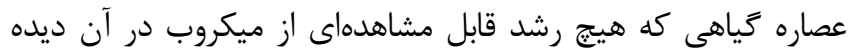
نشد، در نظر كرفته شد (CLSI, 2018). به منظور تعيين حداقل غلظت كشنده نيز از رقتهايى كه هيج

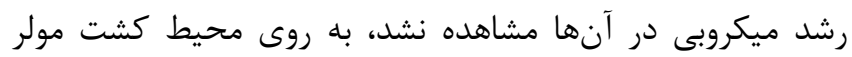

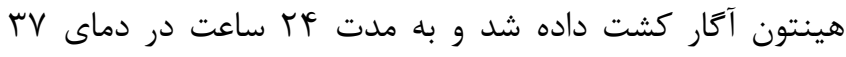

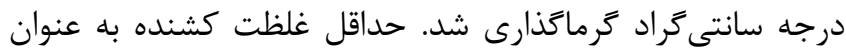

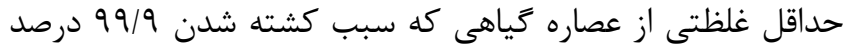
از ميكروار كانيسمها مىشود، تعريف مى شود (CLSI, 2018). بررسى تاثير دماهاى مختلف بر فعاليت ضدميكروبى عصارههاى

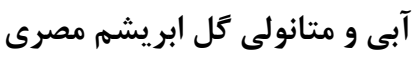

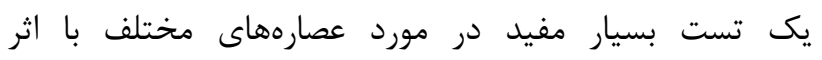
ضدميكروبى، بررسى اثر فاكتورهاى مختلف بر فعاليت آنها است.

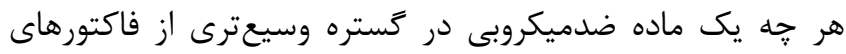

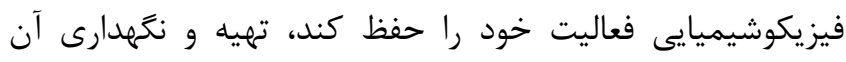

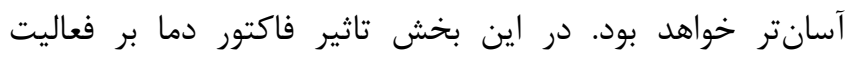

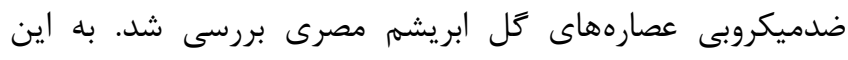

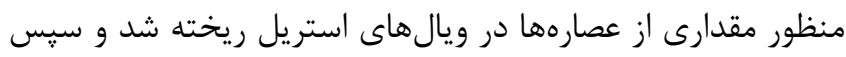

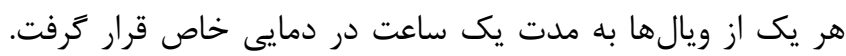
دماهاى مورد استفاده عبارت بودند از دماى اتاق، دماى • · د- درجه سانتى گراد (به منظور بررسى اثر فريز كردن بر فعاليت عصاره) و

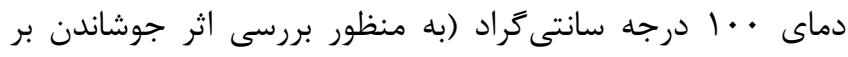

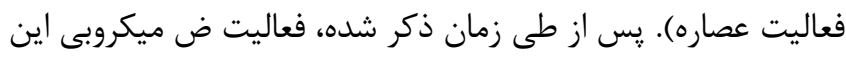

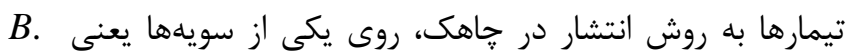




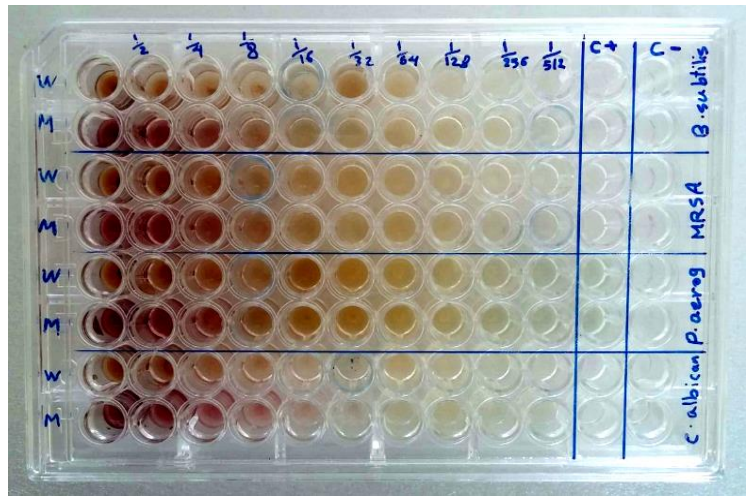

شكل r - سريال رقت از عصارههاى آبى و متانولى كل ابريشم مصرى در ميكرويليت به منظور تعيين حداقل غلظت مهاركننده رشد.

Fig. 2. Serial dilution of water and methanolic extracts of Erythrostemon gilliesii flower in microplate for MIC determination.
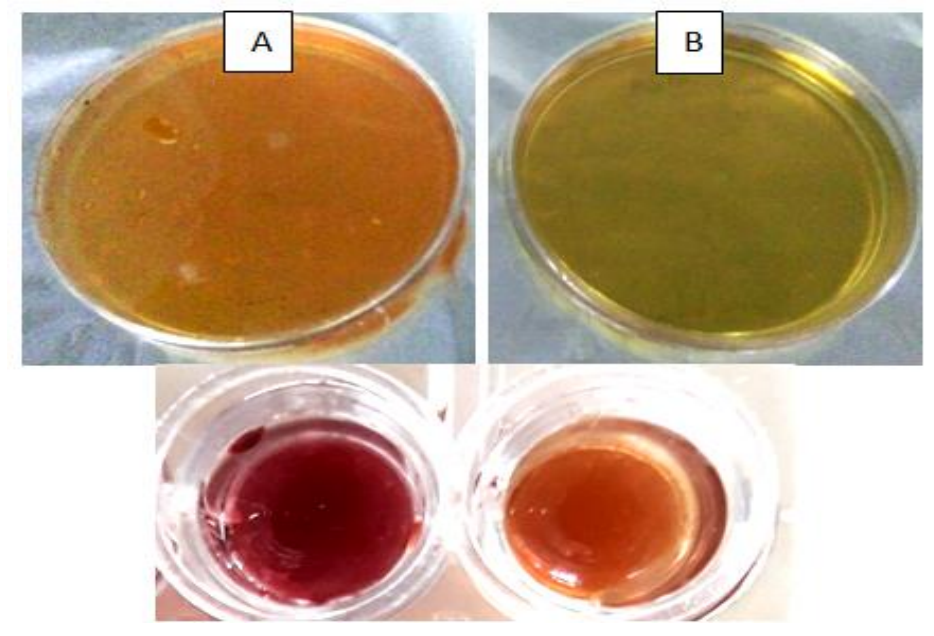

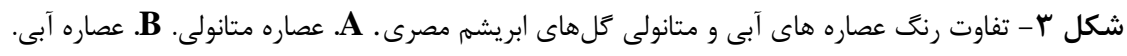

Fig. 3. Difference in color of water and methanolic extracts of Erythrostemon gilliesii flowers. A. methanolic extract. B. water extract.

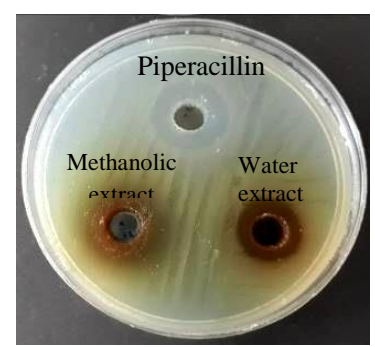

A

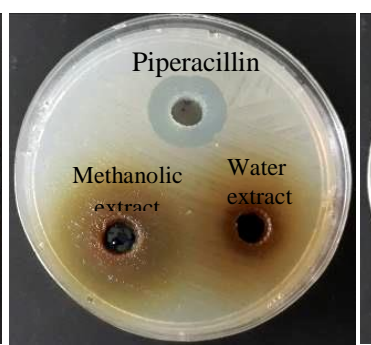

B

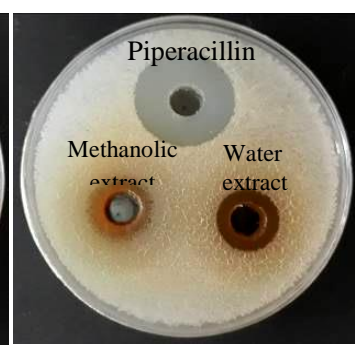

C

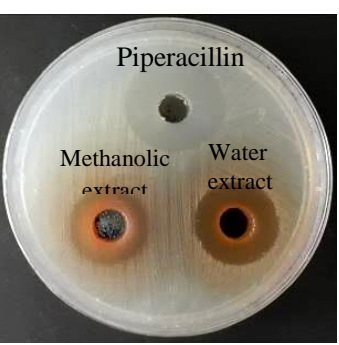

D

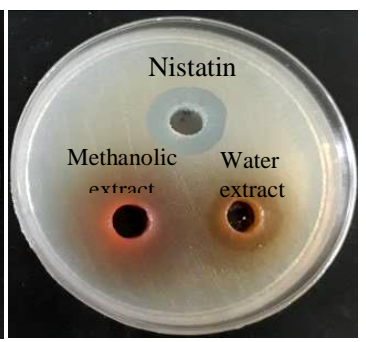

$\mathrm{E}$

شكل F - بررسى وجود هاله عدم رشد ميكرواركانيسمهاى مورد استفاده در مجاورت عصارههاى متانولى و آبى حاصل از گل ابريشم مصرى به روش انتشار خاهك. A C. albicans .E .MRSA .D B. subtilis .C .K. pneumonia .B .P. aeruginosa

Fig. 4. Study on inhibition zone of used microorganisms around the methanolic and water extracts of Erythrostemon gilliesii flowers by well diffusion method. A. P. aeroginosa. B. K. pneumonia. C. B. subtilis. D. MRSA. E. C. albicans. 


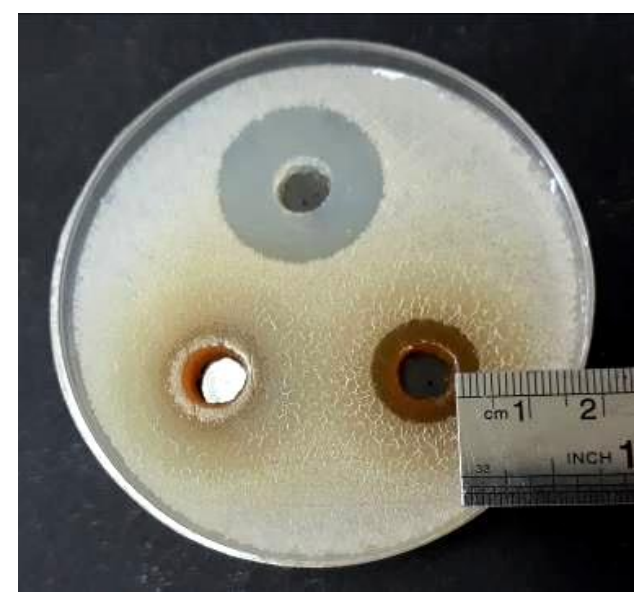

شكل ه - اندازه كيرى هاله عدم رشد از لبه حاهك با خط كش.

Fig. 5. Measurement of inhibition zone from the well edge with ruler.

جدول ا- ميانگين اندازه هاله عدم رشد براى ميكروار گانيسمهاى مورد استفاده.

Table.1. The mean of inhibition zone for used microorganisms

\begin{tabular}{|c|c|c|}
\hline Bacteria & $\begin{array}{c}\text { The mean of inhibition zone for water extract } \\
(\mathrm{mm}+\mathrm{SD})\end{array}$ & $\begin{array}{c}\text { The mean of inhibition zone for methanolic extract } \\
(\mathrm{mm}+\mathrm{SD})\end{array}$ \\
\hline P. aeroginosa & $4+0.05$ & $2+0.02$ \\
\hline K. pneumonia & 0 & 0 \\
\hline B.subtilis & $5+0.03$ & $3+0.05$ \\
\hline MRSA & $9+0.05$ & $7+0.01$ \\
\hline C.albicans & $5+0.01$ & No inhibition zone \\
\hline
\end{tabular}
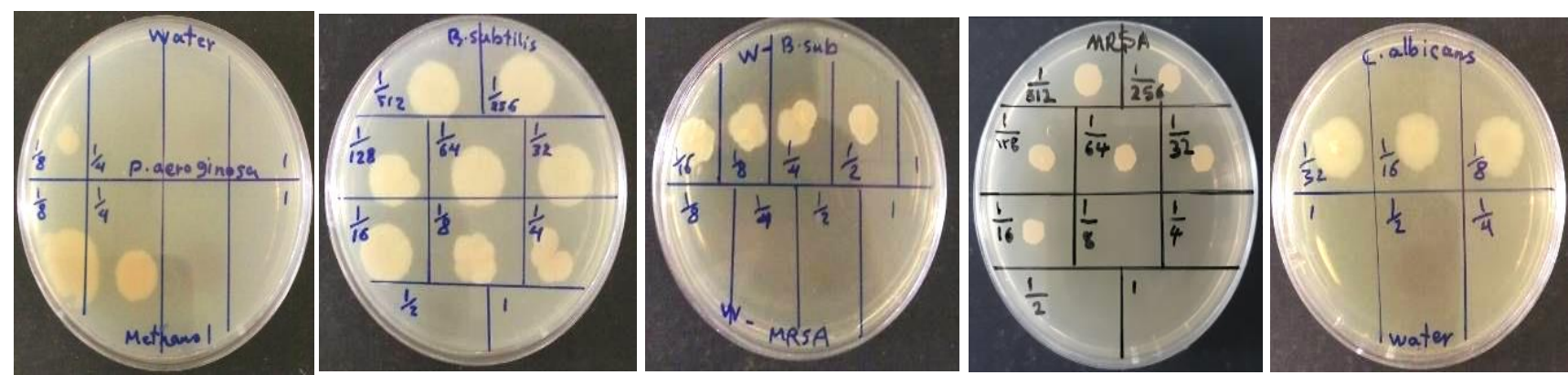

شكل צ - كشت از جاهكها به منظور تعيين حداقل غلظت كشنده عصارههاى كل ابريشم مصرى.

Fig. 6. Cultivation from wells for determination of MBC of extracts of Erythrostemon gilliesii flowers.

جدول r- حداقل غلظت كشنده عصارههاى گل ابريشم مصرى براى سويههاى مورد استفاده.

Table. 2. MBC of extracts of Erythrostemon gilliesii flowers for used microorganisms.

\begin{tabular}{|c|c|c|}
\hline Bacteria & MBC for water extract $(\mathrm{mg} / \mathrm{ml})$ & MBC for methanolic extract $(\mathrm{mg} / \mathrm{ml})$ \\
\hline P. aeroginosa & 60.5 & 95 \\
\hline B.subtilis & 121 & 95 \\
\hline MRSA & 15.12 & 11.87 \\
\hline C.albicans & 30.25 & - \\
\hline
\end{tabular}



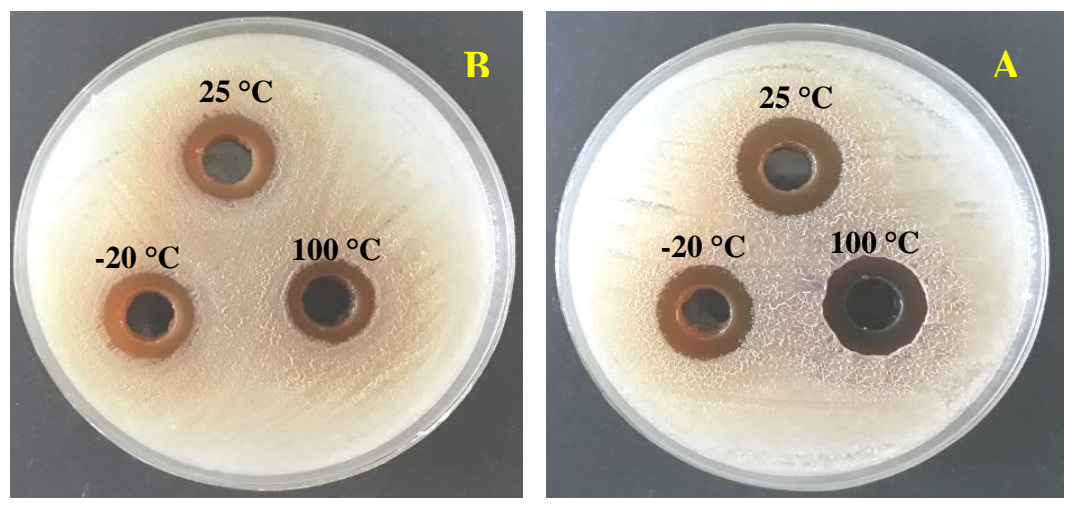

شكل V - اثر دما بر فعاليت ضدميكروبى عصارههاى آبى و متانولى گل ابريشم مصرى. A. عصاره آبى. B. B. عصاره متانولى.

Fig. 7. The Effect of temperature on antimicrobial activity of water and methanolic extracts of Erythrostemon gilliesii flowers. A. water extract. B. methanolic extract.

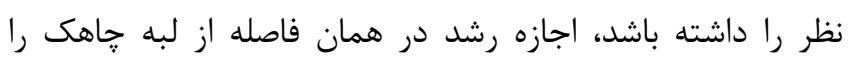

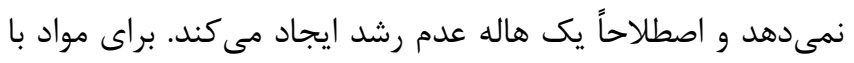

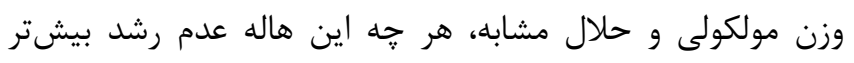

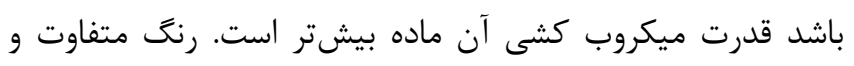

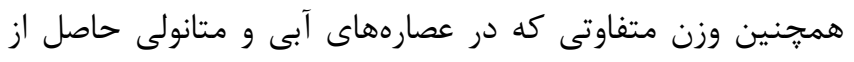

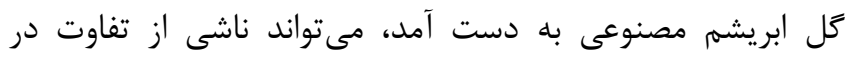

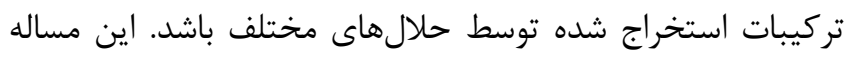

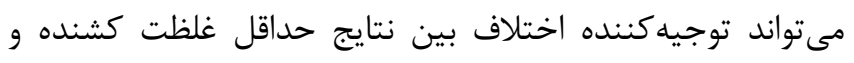

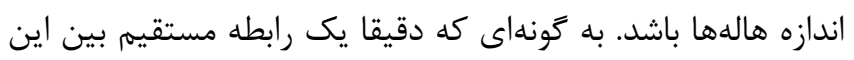

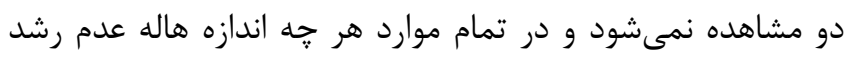

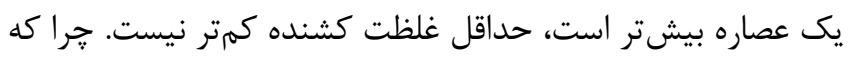

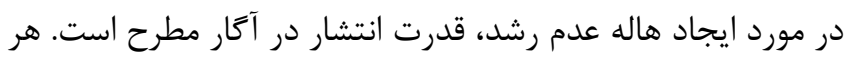

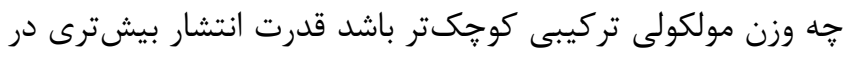

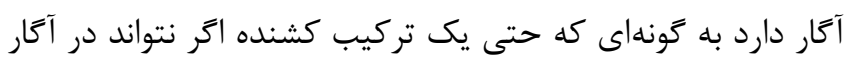

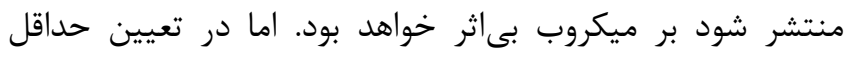

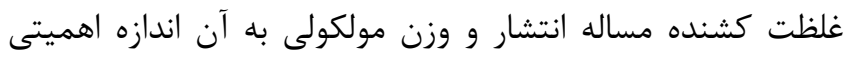

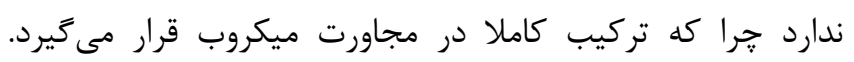

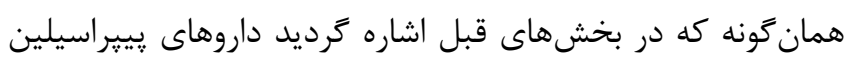

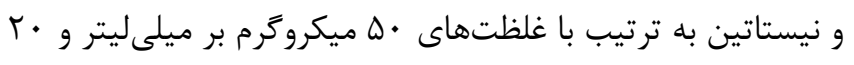

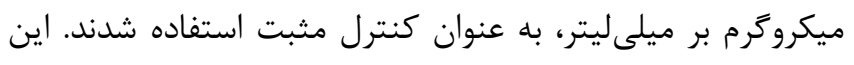
در حالى است كه مثلا براى باكترى مقاومى مانند

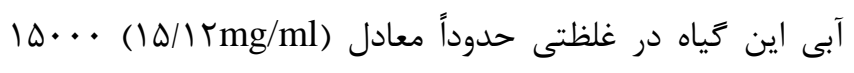

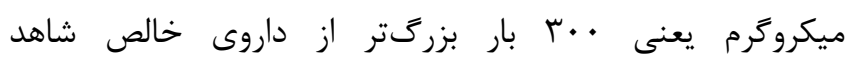

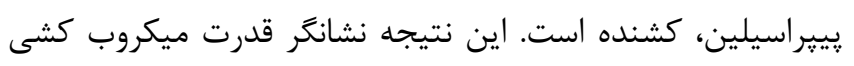

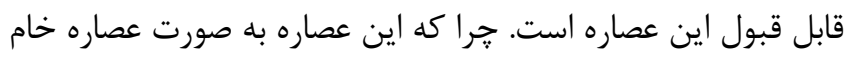

تعيين اثر دماهاى مختلف بر عصارههاى كل ابريشم مصرى

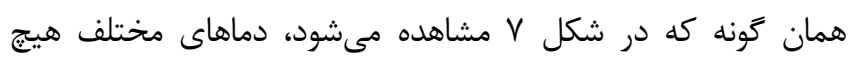

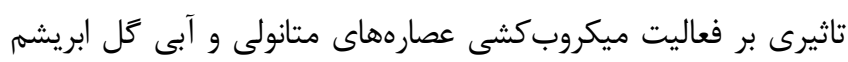

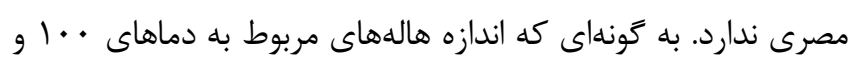

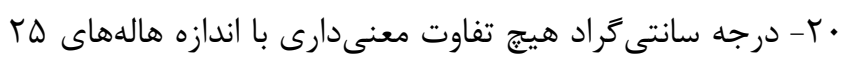

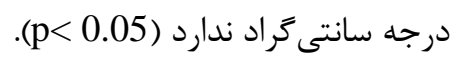

بحث

در اين يزوهش جهت عصارهزيرى از تياه از حلال متانول

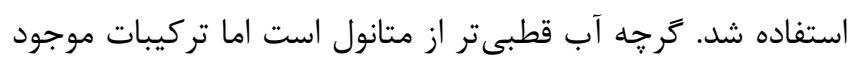

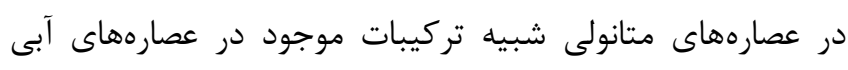

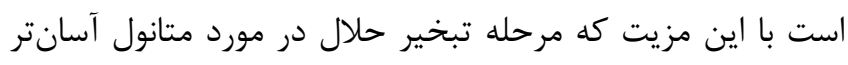

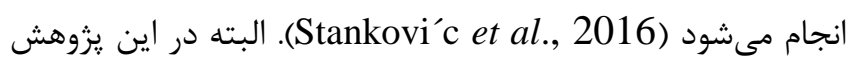

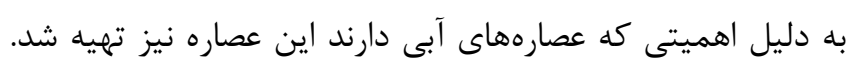

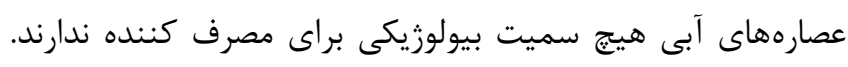

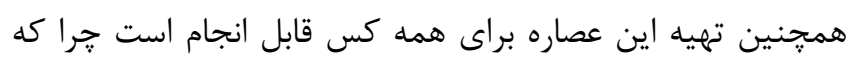

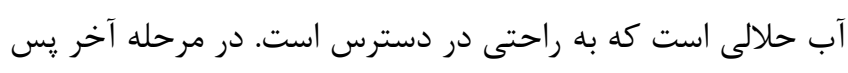

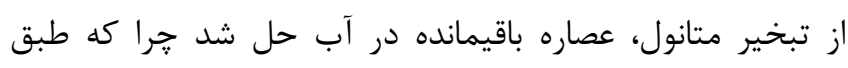

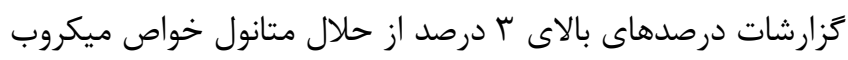

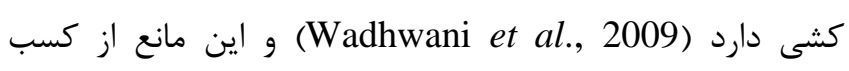
نتيجه صحيح از خواص ضدميكروبى عصاره خياهى خواهد شد.

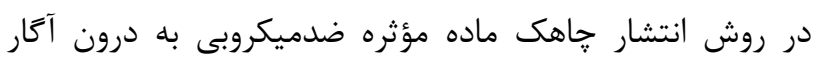

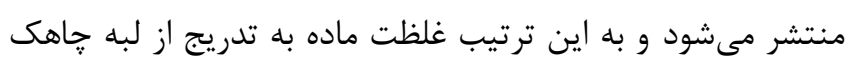

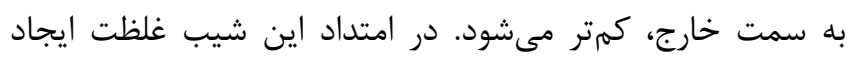

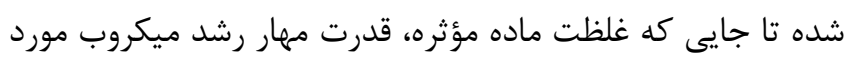


جدول r- نتايج مربوط به يزوهش Dhaked و همكاران (2011).

Table 3. The research results of Dhaked et al., 2011.

\begin{tabular}{|c|c|c|c|c|c|c|}
\hline \multirow{2}{*}{ Bacterial species } & \multicolumn{3}{|c|}{ Zone of inhibition mean diameter in $(\mathrm{cm})$} & \multicolumn{3}{|c|}{ MIC $((\mu \mathrm{g} / \mathrm{ml})$} \\
\hline & Cephalosporin $(\mu \mathrm{g} / \mathrm{ml})$ & Aqueous CPF & Ethanolic CPF & Cephalosporin & Aqueous CPF & Ethanolic CPF \\
\hline Escherichia coli & 15 & 17 & 19 & 18.9 & 16.7 & 15.5 \\
\hline Bacillus subtilis & 13 & 15 & 16 & 22.4 & 15.7 & 14.4 \\
\hline Staphylococcus aureu & 17 & 22 & 20 & 19.1 & 14.8 & 16.3 \\
\hline
\end{tabular}

عفونتهاى حاصل از جدايههاى نامبرده را دارد. يزوهشگران يس از

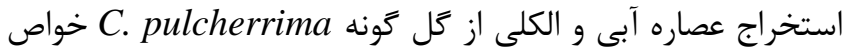
ضدميكروبى آنها را بررسى كردند و مشاهده شد كه اين عصارهها بر وابر باكترىهاى B. coli S. aureus و. Subtilis

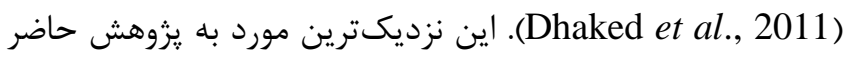
است. جدول ب نشاندهنده خلاصهاى از نتايج به دست آمده در يروهش اين يزوهشخران است. همان گَونه كه مشاهده مى گردد عصارههاى آبى و اتانولى كل هاى گُونه C. pulcherrima غلظتهايى بسيار كمتر از يزوهش حاضر بر سويههاى استاندارد موثرند. يس از بررسى دقيقتر در روش كار و آناليز نتايج اين

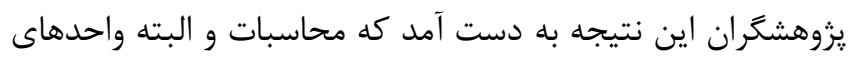
اندازهزيرى بسيار اشتباه هستند. به گَونهاى كه قطعا قطر هاله عدم

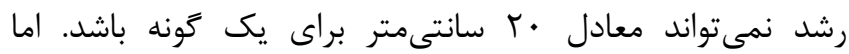
متاسفانه يزوهش نزديكترى به يزوهش در دسترس نيست. نتايج حاصل از تيمارهاى دمايى مختلف بر اثر ميكروبكشى يرى برون عصارههاى كل ابريشم مصرى، نشان دهنده اين بود كه با توجه به بى اثر بودن دماى جوش بر فعاليت اين عصاره مىتوان براى گرفتن

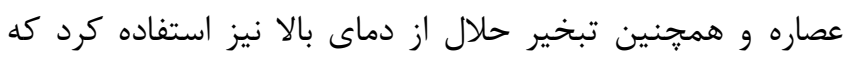
سبب تسريع بسيار زياد عملكرد عصارهگيرى خواهد شد. همجنين بى اثر بودن دماى • r- درجه سانتى گراد بر فعاليت اين عصارهها نشانگر اين است كه مىتوان اين عصارهها را در اين دما نتخهدارى و در زمان طولانىترى استفاده كرد يا روى آنها آزمايش كرد.

$$
\text { نتيجه تَيرى }
$$

با توجه به آنجه كه در بخش نتايج مشاهده شد عصارهاى كل

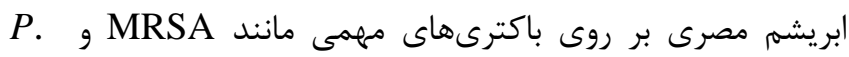
aeroginosa هستند، مؤثر هستند. بنابراين مىتوان اين زل را به عنهان منان منبع
مورد استفاده قرار گرفته است كه حاوى مواد مختلف از جمله ماده ضدميكروبى است. در حالى كه داروهاى شاهد به صورت خالص و تك جزئى است.

E. به منظور مقايسه قدرت ميكروب كثى عصاره استخراجى از زياه gilliesii ديخرى كه روى خواص ضدميكروبى عصارههاى گونههاى ديخر اين درختجه كار كردهاند نيز نشانگر وجود فعاليت ضدميكروبى اين جنس رون است. محققين روى خواص ضدميكروبى عصاره اتانولى ميوههاى خشك گونه C. pulcherrima تحقيق كردند و ززارش كردند كه P. اين عصاره بر طيف وسيعى از باكترىها از جمله E. coli

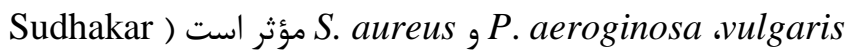
C. . (et al., 2006 pulcherrima خواص ضدباكتريايى است (Prakash et al., 2009). محققان يس از استخراج عصاره متانولى دانه و ميوه C. pulcherrima، به اين نتيجه رسيدند كه اين گونه با داشتن خواص ضدميكروبى عليه طيف وسيعى از باكترىهاى كرم مثبت، منفى و همجنين قارجها و همجنين به واسطه رنج گُائين يتانسيل بسيار بالايى جهت استحصال تركيبات ضدميكروبى مفيد

است (Chanda et al., 2010).

C. روى خواص ضدميكروبى بخش ديخرى از زياه pulcherrima از استحصال عصاره آبى و اتانولى يوسته ساقههاى اين خياه و تاثير P. P. Mirabilis Pآن بر جدايdهاى كلينيكى مختلفى مانند K. g S. typhi ،E. coli S. aureus aeruginosa pneumonia گياه در مقايسه با آنتىبيوتيكهاى تجارى مانند كلرامفنيكل و آميىسيلين، فعاليت بهتر و بالاترى دارد و قابليت استفاده در درمان 


\section{REFERENCES}

Balouiri, M., Sadiki, M. and Ibnsouda, S.K. 2016. Methods for in vitro evaluating antimicrobial activity: A review. - J. Pharm. Analysis 6: 71-79.

Chanda, S., Parekh, J., Baravalia, Y. and Parekh, S. 2010. Antimicrobial and antioxidant efficacy of various solvent extracts of seeds and fruits rind of Caesalpinia pulchecrrima Swartz. - Arch. Clin. Microbiol. 1: (4:5) doi: $10: 3823 / 218$.

CLSI. 2018. Performance standards for antimicrobial susceptibility testing, 28th Edition, CLSI documents M02, M07, and M11. Clinical and Laboratory Standards Institute, 950 West Valley Road, Suite 2500, Wayne, Pennsylvania 19087, USA.

CLSI. 2012. Performance standards for antimicrobial susceptibility testing: Twenty-second informational supplement. CLSI documents M100-S22. Vol 32, No 3, Replaces M100-S21. Vol 31, No 1. Clinical and laboratory standards institute, 950 West Valley Road, Suite 2500, Wayne, Pennsylvania 19087, USA.

Dhaked, P.S., Kshirsagar, S.N. and Sakarar, D.M. 2011. Antimicrobial activity of ethanolic and aqueous extract of Caesalpinia pulcherrima flowers. - IJPSR 2: 2643-2646.

Frey, F. M. and Meyers, R. 2010. Antibacterial activity of traditional medicinal plants used by Haudenosaunee peoples of New York State .BMC Complement Altern. Med. 10: 64-74.

Ginovyan, M., Petrosyan, M. and Trchounian, A. 2017. Antimicrobial activity of some plant materials used in Armenian traditional medicine. - BMC Complementary Alternative Medicine 17: 50-59.

Link, J. H. F., Klotzsch. J. F. and Otto, C. F. 1844. Icones plantarum rariorum horti regii botannici berolinensis. Berlin.

Pirnia, M., Edalatian Dovom, M.R., Tabatabaee Yazdi, F. and Shahidi, F. 2014. The antibacterial effects of the aqueous and ethanolic extracts of cordiamyxa fruit on Staphylococcus aureus, Bacillus cereus, Escherichia coli and Salmonella typhi. - Qom Univ. Medl. Sci. J. 9: 39-48.

Prakash, S.B., Sharmistha, P. and Ravikumar, A. 2009. Antibacterial activity of methanolic extrac of roots of Caesalpinia pulcherrima. - Int. J. Chem. Sci. 7: 16-18.

Ogu, G., Ekeanyanwu, R. and Igborgbor, C. 2010. Phytochemical characteristics and in vitro antibacterial activity of Caesalpinia pulcherrima stem bark extracts against some clinical isolates. - IJONAS 6: 329-336.

Samir, M., Osman, S.M., Abd El-Khalik, S.M., El-Haddad, A.E. and Wink, M. 2015. A new steroidal compound (ß-sitosterol-3-O-butyl) isolated from Caesalpinia gilliesii flowers. - Inl. J. App. Res. Nat. Pro. 8: 14-19.

Sharafati-chaleshtori, R., Sharafati-chaleshtori, F., Sharafati-chaleshtori, A. and Ashrafi, K. 2010. Antimicrobial effects and evaluation of total phenols, flavonoids and flavonols contents of ethanolic extracts of Scrophularia striata. - J Shahrekord Univ. Medl. Sci. 11: 32-37.

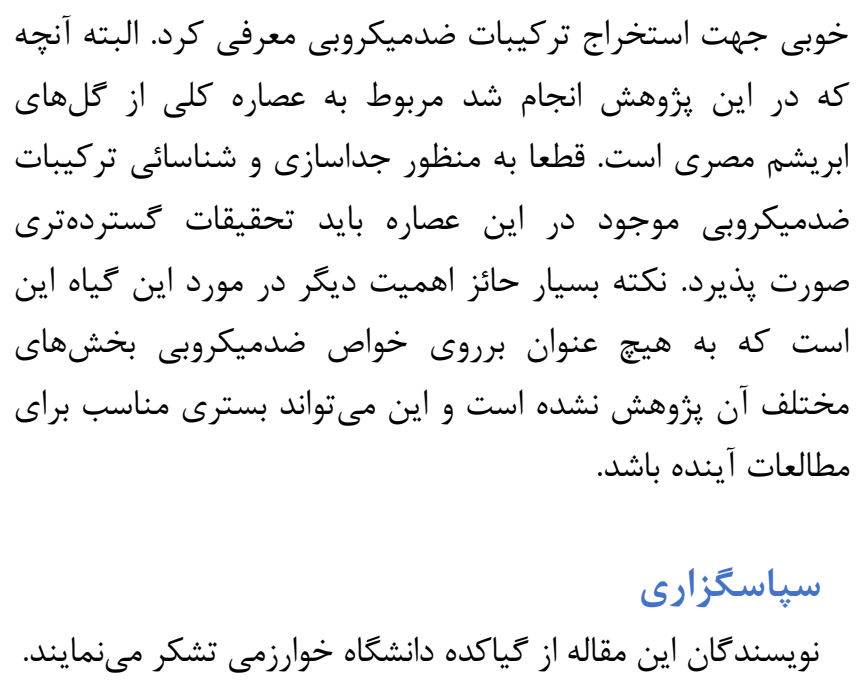


Sharma, A., Chandraker, S., Patel, V.K. and Ramteke, P. 2009. Antibacterial activity of medicinal plants against pathogens causing complicated urinary tract infections. - Indian J. Pharm. Sci. 71: 136-139.

Wadhwani, T., Desai, K., Patel, D., Lawani, D., Bahaley, P., Joshi, P. and Kothari, V. 2009. Effect of various solvents on bacterial growth in context of determining MIC of various antimicrobials. - Internet J. Microbiol. 7: 1-14.

Wangensteen, H., Diallo, D. and Paulsen, B.S. 2015. Medicinal plants from Mali: Chemistry and biology. - J. Ethnopharmacol. 176: 429-437.

West, A.M. Teska, P.J. Lineback, C.B. Oliver, H.F. 2018. Strain, disinfectant, concentration, and contact time quantitatively impact disinfectant efficacy. Antimicrob. Resist. Infect. Control. 7: 49-55.

Stankovi, N., Mihajilov-Krstev, T., Zlatkovi, B., StankovJovanovi, V., Miti, V., Jovi, J., `Comi, L., Koci, B. and Bernstein, N. 2016. Antibacterial and antioxidant activity from of traditional medicinal plants the Balkan Peninsula. - J. Life Sci. 78: 21-28.

Srivastava, J., Chandra, H., Nautiyal, A. and Kalra, S. 2013. Antimicrobial resistance (AMR) and plantderived antimicrobials (PDAms) as an alternative drug line to control infections. - Biotech. 4: 451-60.

Sudhakara, M., Rao, Ch.V., Rao, P.M., Rajua, D.B. and Venkateswarlu, Y. 2006. Antimicrobial activity of Caesalpinia pulcherrima, Euphorbia hirta and Asystasia gangeticum. - Fitoterapia 7: 378-380.

Tomova, I., Stoilova-Disheva, M., Lazarkevich, I. and Vasileva-Tonkova, E. 2015. Antimicrobial activity and resistance to heavy metals and antibiotics of heterotrophic bacteria isolated from sediment and soil samples collected from two Antarctic islands. - Front Life Sci. 8: 348-357.

How to cite this article:

Tafakori, V. and Nasiri, N. 2020. Anti-microbial effects of aqueous and methanolic extracts of Erythrostemon gilliesii. Nova Biol. Reperta 6: 454-463. (In Persian)

$$
\text { تفكرى، و. و نصيرى، ن. }
$$

